\title{
不動態皮膜の劣化やコンクリートの乾湿が 電気伝導特性に及ぼす影響に関する研究
}

\author{
吉田秀典 ${ }^{1} \cdot$ 大本修平 $^{2}$ \\ 1香川大学教授 工学部安全システム建設工学科（† 761-0396 香川県高松市林町 2217-20） \\ E-mail: yoshida@eng.kagawa-u.ac.jp \\ 2 元香川大学学生
}

\begin{abstract}
コンクリート構造物の老朽化や公共事業の縮減に伴い，既存のコンクリート構造物を長期的に運用していく 必要がある。その際に，構造物の維持管理上から，早期にコンクリート内の鉄筋腐食状態等を非破壊モニタリ ングする技術が望まれている。そのような中，コンクリート中の鉄筋の腐食速度の推定と腐食の定量評価が可 能である分極抵抗法が注目されている。しかしながら, 研究に関しては基礎的なレベルの事案が多く, 不動態 皮膜の劣化やコンクリートの乾湿が電気伝導特性に及ぼす影響について論ぜられていないのが実態である. そ こで本研究では, 有限要素解析を行い, 不動態皮膜の劣化やコンクリートの乾湿が電気伝導特性に及ぼす影響 について検討した。 その結果, 両因子が電気伝導特性に影響を及ぼすこと, 特に, コンクリートの乾湿は大き な影響を及ぼすことが判明した。
\end{abstract}

Key Words: Degradation of passivation film, Wetting and drying of concrete, Property of electrical conduction

\section{1.はじめに}

わが国では，戦後の高度成長期にコンクリート構造 物が集中的に建設された。この時期に大量に建設され た鉄筋コンクリート構造物については，品質に相当の ばらつきがみられ，多くの構造物において，様々な変 状が報告されており，今後，少なからず更新せざるを 得ないものも出てくることが予想される.

国土交通省によると全国で $15 \mathrm{~m}$ 以上の橋梁が約 14 万 橋ある.このうち， 50 年以上経過した橋は，2006 年度 に 8,900 橋（全体の $6 \%$ ），2016 年度 28,400 橋（全体の $20 \%$ ），そして 2026 年度 66,300 橋（全体の 47\%）に達 する ${ }^{1)}$ 。しかしながら, 近年では公共事業の縮減によ り, 既存のコンクリート構造物を建て替えるというこ とは考えられにくく, 既存のコンクリート構造物を維 持管理しながら長期的に運用していく必要がある ${ }^{2)}$.

鉄筋コンクリート構造物を長寿命化させるには，コ ンクリートや鉄筋の劣化の原因と程度を探り，適切な 処置を施す必要があるが, 構造物を供用しながら劣化 の原因や程度を探ることになるので，構造物を破壊す ることなく検査すること, つまり, 非破壊検査が望ま れる.ここでコンクリート中にある鉄筋に焦点を当て ると, その非破壊検査法には超音波法や電磁波法, 電 気化学的手法などがあり, 電気化学的手法が多用され ている. 電気化学的手法には自然電位法 3$), 4)$ や分極抵

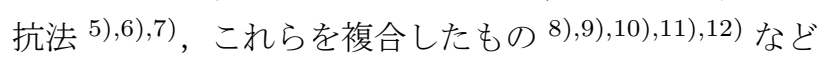

様々なものがあるが，分極抵抗法では鉄筋の腐食速度 を推定することが可能であり，鉄筋の腐食を定量的に 評価できる13)ことからこの手法が注目されている.

\section{2. 分極抵抗法の概要}

分極抵抗法に関する既往の研究としては，実験的 研究と数值解析的研究に分けられる. 実験的研究と して，分極抵抗法によるコンクリート中の鉄筋腐食 評価の有効性が独立行政法人土木研究所 14) や横田 ら 15),16),17),18),19),20) によって検討されている。横田 らは電気的に分割された径 $13 \mathrm{~mm}$ の鉄筋を, かぶり $30 \mathrm{~mm}$, 間隔 $150 \mathrm{~mm}$ に井桁状に配筋した平板タイプ のコンクリート試験体（寸法 : 縦 $700 \mathrm{~mm} \times$ 横 $700 \mathrm{~mm}$ ×厚さ $100 \mathrm{~mm}$ ) を対象に, コンクリート表面に設置し たセンサー（対極）から内部鉄筋への電流分散状況を 調へ，腐食している場合にはセンター対極直下の鉄筋 に電流が集中することを確認するとともに，2 重対極方 式の有効性を報告している ${ }^{21)}$. しかしながら, 電流分 散範囲は鉄筋の腐食だけでなく, 鉄筋径やかぶり, さら には躯体内の水分量等の影響を受けることから 22),23), 本来はこれらのパラメータを変化させて多数の組み合 わせで実験などを行う必要がある。多数の供試体を作 製して実験を行うことは困難をともなうことに加え, 実 験ではコンクリート内の電流分散状況の把握が難しい ことから，数值解析による検討が有用となる. 
これを受けて，金田らは境界要素法を用いて電流分 布シミュレーションを行い, 電流分布状況の把握など

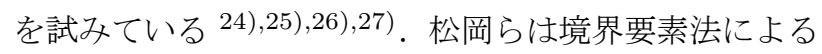
電流分布シミュレーションにより, 鉄筋径やかぶりなど が変化した場合の電流の拡散傾向を確認できることを 示した ${ }^{28)}$. しかしながら, コンクリート構造物の内部 は不均一であること, また, 鉄筋の腐食が全面的では なく部分的であることや，躯体の乾燥等が一律でない ことも考えられることから，材料の非均一性が考慮さ れない境界要素解析には限界がある．材料の非均一性 を考慮できる有限要素法を用いた電流伝導解析を行っ ている事例もあるが，鉄筋コンクリートの非均一性の 影響を検討するには至っていない ${ }^{29)}$.

一方で，コンクリートの乾湿と抵抗率の関係性につ いての研究も行われており 30),31)，コンクリートの抵 抗率に対する乾湿の影響は大きいことが分かっている. また，コンクリートは一様に乾燥が起きるとは考えに くく, 表面と内部では含水率は異なり, 劣化によりひ び割れが生じ, その付近の乾燥が局所的に進む. 既往 の研究では, コンクリートの非均一性に着目した解析 事例はほとんどないが, 鉄筋の非均一性だけでなくコ ンクリートの非均一性も電気分散範囲に影響を与える と考えられる. そこで本研究では, 鉄筋表面の不動態 皮膜の劣化による分極抵抗の非均一性ならびにコンク リートの乾湿にともなう抵抗率の非均一性を考慮した 電気伝導解析を行い，こうした非均一性が電流分散状 況に及ぼす影響について調べることを目的とする.

\section{3. 基礎理論の概要}

静電場が満たす方程式は，マクスウェルの方程式の 時間の項を省いた次式となる.

$$
\begin{gathered}
\nabla \cdot D=q \\
\nabla \times E=0
\end{gathered}
$$

ここで, $D$ は電束密度, $E$ は電場の強さ, そして $q$ は 電荷密度である.ただし, 物質中では

$$
D=\epsilon E
$$

の関係がある.ここで, $\epsilon$ は誘電率である.ここでは等 方的な物質を考えることとする。こうすることで, 誘 電率はスカラー量として取り扱うことができ, 計算が 簡単になる. 静電場の問題は, すべて電束密度と電場 の関係式 (3) を用いて, 連立偏微分方程式 (1) と (2) を 解くことになる.

通常, 静電場の問題では, 電場 $E$ を計算するよりも ポテンシヤルを計算する方が簡単である. 電場はべクト ルで未知数が 3 個あるが，ポテンシャルはスカラーな ので未知数が 1 個で済む。このポテンシャル $\phi$ は, 正
確にはスカラーポテンシャルと称され,

$$
E=-\nabla \phi
$$

と定義される．こうすることにより，マクスウェルの 方程式 (2) が満足される.

これにて, 静電場のマクスウェルの方程式の一つが 満足されたので, 残りの一つを満足させるためのスカ ラーポテンシャルの条件を探せばよい. 式 (1), 式 (3) および式 (4)より,

$$
q=\nabla \cdot D=\nabla \cdot \epsilon E=-\nabla(\epsilon \nabla \phi)
$$

が導かれる.これが静電場を計算する際のスカラーポ テンシャルが満たすべき偏微分方程式である. 右辺と 左辺を入れ替えて, 改めて式を示すと

$$
\nabla(\epsilon \nabla \phi)=-q
$$

となる.ここで, 誘電率を一定值とすると微分の外に出 すことができ, 次のようなポアソン方程式が得られる.

$$
\nabla^{2} \phi=-\frac{q}{\epsilon}
$$

また, 計算する領域内に電荷がない場合は, 次のよう なラプラス方程式が得られる.

$$
\nabla^{2} \phi=0
$$

式 (8) を改めて示すと, 次のようになる.

$$
\frac{\partial^{2} \phi}{\partial x^{2}}+\frac{\partial^{2} \phi}{\partial y^{2}}+\frac{\partial^{2} \phi}{\partial z^{2}}=0
$$

ここで，境界条件が以下のように

$$
\begin{gathered}
S_{1}: \phi=\phi_{B} \\
S_{2}: \frac{\partial \phi}{\partial n}+\bar{q}=0
\end{gathered}
$$

と与えられるとする. ここで, $\phi_{B}$ は Dirichlet 境界 $S_{1}$ にて与えられる既定ポテンシャル, $\bar{q} は$ Neumann 境界 $S_{2}$ にて流れ出る既定電流量, $n$ は単位法線ベクトルで ある. 式 (9) を, 境界条件式 (10), 式 (11) の下で解く ことは, 次式の汎関数を最小にすることと等価である.

$$
\begin{aligned}
I= & \int_{V} \frac{1}{2}\left\{\left(\frac{\partial \phi}{\partial x}\right)^{2}+\left(\frac{\partial \phi}{\partial y}\right)^{2}+\left(\frac{\partial \phi}{\partial z}\right)^{2}\right\} d V \\
& +\int_{S_{2}} \bar{q} \phi d S
\end{aligned}
$$

いま，

$$
\begin{gathered}
\{g\}=\left\{\begin{array}{c}
\frac{\partial \phi}{\partial x} \\
\frac{\partial \phi}{\partial y} \\
\frac{\partial \phi}{\partial z}
\end{array}\right\} \\
\{g\}^{T}=\left\{\begin{array}{lll}
\frac{\partial \phi}{\partial x} & \frac{\partial \phi}{\partial y} & \frac{\partial \phi}{\partial z}
\end{array}\right\}
\end{gathered}
$$

とすると, 式 (12) は

$$
I=\int_{V} \frac{1}{2}\left[\{g\}^{T}\{g\}\right] d V+\int_{S} \bar{q} \phi d S
$$

となる． 
解析対象を有限な要素に分割し, 要素内の電流分布 を次のように表現する。

$$
\phi(x, y, z)=[N(x, y, z)]\{\Phi\}
$$

ここで, $[N]$ は節点の状態量と要素内の状態量を結びつ ける形状関数マトリックスであり，\{ $\Phi\}$ は各節点にお ける要素の節点状態量を示す. $\{g\}$ を形状マトリックス $[N]$ で表わすと

$$
\begin{aligned}
\{g\} & =\left\{\begin{array}{c}
\frac{\partial \phi}{\partial x} \\
\frac{\partial \phi}{\partial y} \\
\frac{\partial \phi}{\partial z}
\end{array}\right\} \\
& =\left[\begin{array}{llllll}
\frac{\partial N_{1}}{\partial x} & \frac{\partial N_{2}}{\partial x} & \frac{\partial N_{3}}{\partial x} & \ldots & \ldots & \frac{\partial N_{n}}{\partial x} \\
\frac{\partial N_{1}}{\partial y} & \frac{\partial N_{2}}{\partial y} & \frac{\partial N_{3}}{\partial y} & \ldots & \ldots & \frac{\partial N_{n}}{\partial y} \\
\frac{\partial N_{1}}{\partial z} & \frac{\partial N_{2}}{\partial z} & \frac{\partial N_{3}}{\partial z} & \ldots & \ldots & \frac{\partial N_{n}}{\partial z}
\end{array}\right]\left\{\begin{array}{c}
\Phi_{1} \\
\Phi_{2} \\
\vdots \\
\Phi_{n}
\end{array}\right\} \\
& =[B]\{\Phi\}
\end{aligned}
$$

となり, 式 $(17)$ の $[B]$ は形状関数マトリックスを微分 したマトリックスである. 式 (15) の右辺に上記マトリッ クス $[B]$ を用いると，

$$
\begin{gathered}
\int_{V} \frac{1}{2}\{g\}^{T}\{g\} d V=\int_{V} \frac{1}{2}\{\Phi\}^{T}[B]^{T}[B]\{\Phi\} d V \\
\int_{S} \bar{q} \phi d S=\int_{S} \bar{q}[N]\{\Phi\} d S
\end{gathered}
$$

となり，これらを式 (15) に代入すると，

$$
I=\int_{V} \frac{1}{2}\{\Phi\}^{T}[B]^{T}[B]\{\Phi\} d V+\int_{S_{2}} \bar{q}[N]\{\Phi\} d S
$$

となる. $I$ の最大值を求めるために, 式 $(20)$ を $\{\Phi\}$ で 微分する. 具体的には, $\{\Phi\}^{t}[A]\{\Phi\}$ を $\{\Phi\}$ で微分する ことになるが,

$$
\frac{\partial}{\partial\{\Phi\}}\left(\{\Phi\}^{T}[A]\{\Phi\}\right)=2[A]\{\Phi\}
$$

であることより，式 (20) の右辺第 1 項は

$\frac{\partial}{\partial\{\Phi\}}\left(\int_{V} \frac{1}{2}\{\Phi\}^{T}[B]^{T}[B]\{\Phi\} d V\right)=\int_{V}[B]^{T}[B]\{\Phi\} d V$

\section{右辺第 2 項は}

$$
\frac{\partial}{\partial\{\Phi\}}\left(\int_{S_{2}} \bar{q}[N]\{\Phi\} d S\right)=\int_{S_{2}} \bar{q}[N]^{T} d S
$$

となる.したがって，

$$
\frac{\partial I}{\partial\{\Phi\}}=\int_{V}[B]^{T}[B]\{\Phi\} d V+\int_{S_{2}} \bar{q}[N]^{T} d S=0
$$

となる. 以上より求められた式は

$$
[K]\{\Phi\}+\{F\}=0
$$

と表される。ただし，

$$
\begin{aligned}
& {[K]=\int_{V}[B]^{T}[B] d V} \\
& \{F\}=\int_{S_{2}} \bar{q}[N]^{T} d S
\end{aligned}
$$

である。

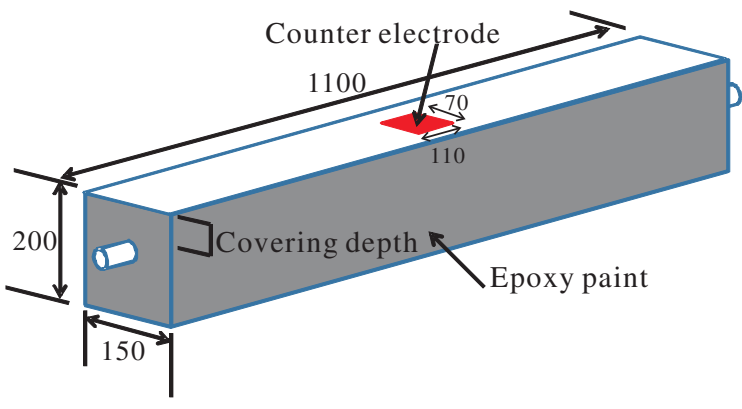

図-1 供試体概略

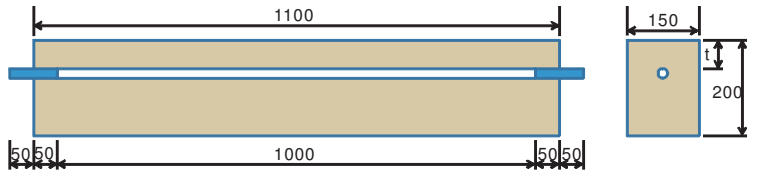

図-2 供試体のサイズ

\section{4. 解析対象とそのモデル化}

鉄筋コンクリート中の電流分散状況を把握するため に, 供試体中央（図-1 中の上面の短形領域）のコンク リート表面に電圧を印加し, 不動態皮膜部の劣化やコ ンクリートの乾湿がコンクリート中の電流分散状況に 及ぼす影響について検討するために，不動態皮膜の分 極抵抗やコンクリートの電気抵抗率を変化させて 3 次 元有限要素解析を実施する.

\section{（1）供試体寸法}

解析では，図-1，図-2 に示すようなコンクリート供 試体を用いる。なお，本論文では，紙面に限りがある ことから鉄筋径を $25 \mathrm{~mm}$ (図には示してない)，かぶ り（図中の $t$ ）を $60 \mathrm{~mm}$ とした解析例についてのみ示 すこととする.また，以降に示すメッシュ等では，不動 態皮膜部を除き，長さの単位を $\mathrm{mm}$ としている.

\section{(2) 解析メッシュ}

図-1，図-2 を基に解析メッシュを作成した。供試体 中央の鉄筋直上のコンクリート表面に対極を設置した 場合, 対称性を勘案することで有限要素解析の節点およ び要素数の削減が可能となることから，図-1に示す全 体領域の 4 分の 1 を解析対象領域とした. 解析領域なら びに解析メッシュを図-3 と図-4 に示す. 図-4 の凡例 の Concrete はコンクリート要素を, Rebar は鉄筋要素 を, Passivation film / Corrosion はコンクリートと鉄 筋の境界部要素（不動態皮膜部）を，Isolation は絶縁 要素を, そして Impress は電圧印加領域を表している. コンクリートと鉄筋の境界部付近を拡大した図-5に示 すように，鉄筋要素，境界部要素，そしてコンクリー 


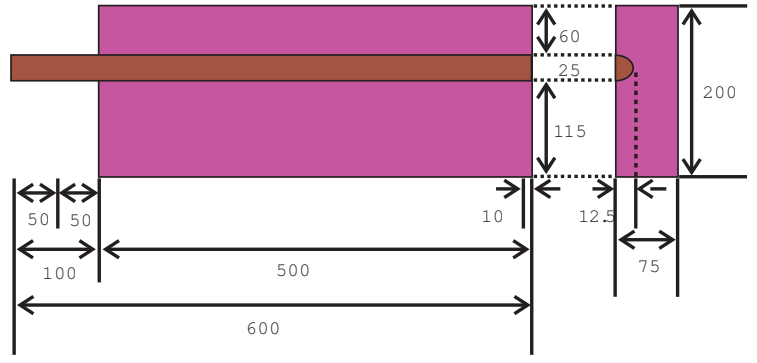

図-3 解析領域（D25，かぶり $60 \mathrm{~mm}$ )

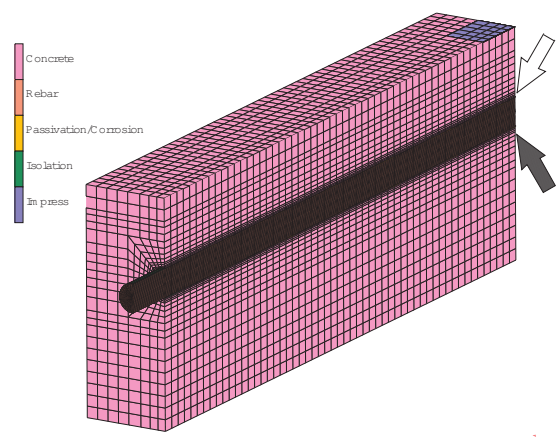

図-4 解析メッシュ（D25，かぶり 60mm）

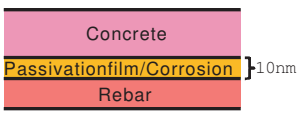

図-5 不動態皮膜部

卜要素を配置し，図-2 に示す通り，コンクリートと鉄 筋の境界部のうち鉄筋端から $100 \mathrm{~mm}$ を絶縁部（図中， 両端部の青色部分，絶縁要素）としている. 絶縁要素 については，この要素の電気抵抗を極めて大きくする $\left(1.0 \times 10^{16} \mathrm{k} \Omega \mathrm{cm}\right.$ で，通常の鉄筋の $10^{21}$ 倍以上）こと で表現した。なお，要素はすべて 8 節点六面体要素（ア イソパラメトリック要素) で, 総節点数は 31,784 , 総 要素数は 28,392 である.

\section{(3) 電気抵抗率}

本解析は，簡単に言えばオームの法則 $(V=R I)$ に 従うような問題を解くことになるので，与えられた電 位 $(V)$ に対して, 求まるのは電流 $(I$, あるいは電流 密度 $J)$ であり，材料特性として抵抗 $(R$ ，あるいは抵 抗率 $\rho$ ）を与える.

一般に，コンクリートの表面が水に接している環境 を除いて，コンクリートは表面近傍が乾燥して抵抗率 が大きく，内部では相対的に湿度が高いため抵抗率が 小さい状態となっている．金田ら ${ }^{32)}$ は表面近傍と内 部の抵抗率にどの程度であるかを調べるために，比抵 抗測定用の電極（ステンレス棒）を埋め込んだコンク リート試験体を作製し，異なる環境（恒温養生室や屋
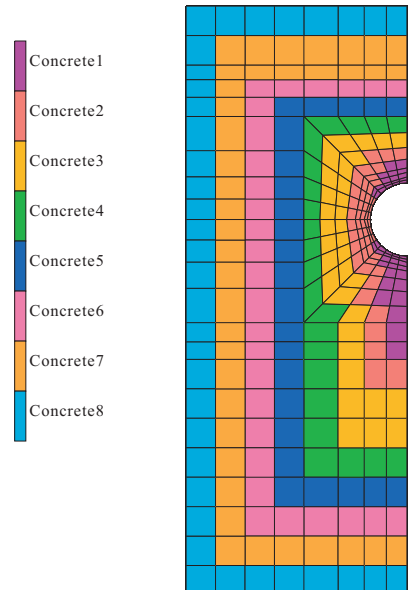

図-6 コンクリートの乾燥状態と抵抗率

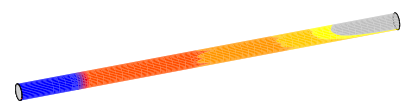

図-7 鉄筋の表面の電流密度の一例

表-1 養生期間とコンクリート抵抗率の関係

\begin{tabular}{|c|c|c|c|c|c|c|c|c|}
\hline 養生 & \multicolumn{7}{|c|}{ コンクリート抵抗率 $\rho(\mathrm{k} \Omega \mathrm{cm})$} \\
\cline { 2 - 9 } 期間 & 1 & 2 & 3 & 4 & 5 & 6 & 7 & 8 \\
\hline 30 週 & 20 & 23 & 26 & 29 & 32 & 35 & 48 & 60 \\
\hline 50 週 & 25 & 32 & 39 & 46 & 53 & 60 & 105 & 150 \\
\hline 70 週 & 35 & 48 & 61 & 74 & 87 & 100 & 160 & 220 \\
\hline 90 週 & 40 & 62 & 84 & 106 & 128 & 150 & 230 & 310 \\
\hline 98 週 & 40 & 68 & 96 & 124 & 152 & 180 & 305 & 430 \\
\hline
\end{tabular}

外）で暴露して深さごとの抵抗を測定している．本研 究では, 金田ら ${ }^{32)}$ が行った測定のうち, 水セメント比 （W/C） 40\%で恒温養生を行った際のコンクリートの 抵抗率を用いて解析を行う (表-1 参照) 。金田らはコ ンクリート表面から $10 \mathrm{~mm}, 20 \mathrm{~mm}, 60 \mathrm{~mm}$ にて抵抗 率を測定しているので, 解析では, 測定值を一次関数 で補間した值を用いる。なお，コンクリート表面から $60 \mathrm{~mm}$ より深部ではコンクリートの抵抗率は一定とし, 深度 $60 \mathrm{~mm}$ の点で読み取った值を用いる. コンクリー 卜表面より深さごとの乾燥に伴う抵抗率を設定するた めに図-6に示すような要素割を行う。要素ごと（表中 の $1,2, \cdots$ が図中の Concrete1, Concrete $2 \cdots$ に対 応）かつ養生期間ごとの抵抗率を表-1 に示寸.

不動態皮膜以外の鉄筋部分については，理科年表に示

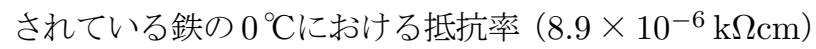
を採用し，すべての解析ケース（養生期間）でこれを 用いた。 また，解析では，次式を用いて，真の分極抵 抗 $R_{p}=R_{p}^{\prime} \times A$ を抵抗率 $\rho_{p}$ に換算し, 解析パラメー タとした。

$$
\rho_{p}=\frac{R_{p}^{\prime} \times A}{l}=\frac{R_{p}}{l}
$$


ここで, $R_{p}^{\prime}$ はみかけの分極抵抗 $(\Omega), l$ は不動態皮膜 の厚さ， $A$ は被測定面積である. みかけの分極抵抗を 測定する場合, 通常, センター対極 (CCE) とガード 対極（GCE）という2つの対極センサーを用いて測定 を行っており，2つの対極のうち CCE に流れる電流を 計測している. 全電流量のうち, 約 $30 \%$ CCE に流れ ることが実験にて確認されていて ${ }^{13)}$, 本研究では, こ の範囲を「被測定面積」と称している。この範囲が広い ほど電流は広く拡散する, つまり不動態皮膜は健全で, 逆に，狭いほど電流は狭い範囲に留まっている，つまり 不動態皮膜が劣化している，あるいは損傷等を受けて いることを示唆する．図-7 は鉄筋表面の電流密度の一 例であるが，被測定面積が広いというのは，全電流量 の約 $30 \%$ CCE に流れる領域が，例えば，図の灰色か らオレンジまでの領域に該当するのに対し，狭い場合 は，灰色の領域のみが該当するというようなイメージ である. 不動態皮膜は $2 \mathrm{~nm} \sim 6 \mathrm{~nm}$ というのが一般的で あるが 33), 本解析では, やや大きめに $10 \mathrm{~nm}$ とした. なお，本研究では，不動態皮膜が部分的あるは全面的 に劣化するという設定をすることで鉄筋コンクリート における非均一性を議論するため, 分極抵抗の抵抗率 については, 様々なパターンを用いている. そのため, その值については, 次小節にて示寸各解析ケースごと に詳細に説明することとする.

\section{（4）境界条件}

境界条件に関しては，供試体上部（図-1における上 面中央の矩形領域）に $10 \mathrm{mV}$ を印加し，鉄筋端を $0 \mathrm{~V}$ とした。 なお, 実際の測定器のセンサ部は円形（断面 積: 約 $72 \mathrm{~cm}^{2}$ ) であるが，解析メッシュは直方体を基 本としていることから, 解析におけるセンサ部（印加 箇所）の領域については, 実際の機器の面積と同じに なるように矩形領域にて設定した.

\section{5. 解析結果と考察}

本節では, 不動態皮膜における分極抵抗の值, 劣化 箇所とその大きさ，そしてコンクリートの乾湿が躯体 内の電流伝播に及ぼす影響の把握を目的として実施し た解析について考察を行う。

\section{（1）不動態皮膜の劣化箇所と劣化程度について}

本小節では，不動態皮膜の一部のみが劣化している 場合に，その箇所ならびに低下した分極抵抗の值が被 測定面積および電流伝播に及ぼす影響の把握を目的と して解析を行った. 劣化部では, 劣化していない䇢所 の分極抵抗值（本論文では, 全ての解析で $1000 \mathrm{k} \Omega \mathrm{cm}^{2}$ と設定）と比較して抵抗值が小さくなるが，どの段階で

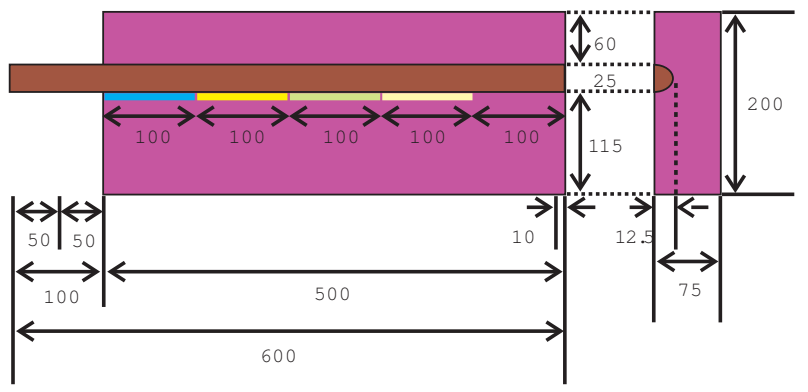

図-8 劣化箇所配置図

どの程度の劣化になるかについては不明な点も多いこ とから，本解析では，簡易的に半分， 10 分の 1 , そして それらの間をとって 5 分の 1 という 3 パターンを考え, 本研究では, これらを「分極抵抗比=劣化部の分極抵 抗值／健全部の分極抵抗值」と定義する. また，その箇 所も供試体の中央（図-8 の右端）から $100 \mathrm{~mm}$ （図-8 のクリーム色の領域), $200 \mathrm{~mm}$ (図-8 の緑色の領域), $300 \mathrm{~mm}$ （図-8 の黄色の領域）ならびに $400 \mathrm{~mm}$ （図-8 の青色の領域）の 4 パターンを考え，その劣化領域の 大きさは, 全ての解析において $100 \mathrm{~mm}$ としている. な お，本小節では，不動態皮膜の劣化の影響のみを考察 したいことからコンクリートについては乾湿等の影響 は考慮せず, 全てのコンクリート要素にて一定の抵抗

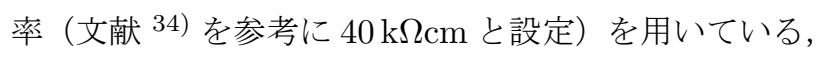
まず， $100 \mathrm{~mm}$ の劣化領域を供試体の中央（図-8 の 右端）から $100 \mathrm{~mm}$ のところ（図-8のクリーム色の領 域）に設け，分極抵抗比のみを変化させた場合につい て考察する。この場合の電流密度分布図を, 図-9 から 図-12 に示寸. 図より，分極抵抗比を小さくすると，劣 化領域一の電流の流れ込みと鉄筋下部からの電流の流 入がより顕著になることがわかる. 劣化領域への電流 の流れ込みと鉄筋下部への回りこみが顕著となると, 劣 化領域より遠方（図-8における左側方向）一の電流の 広がりはほとんど認められないことがわかる。例えば, 電流密度 0.3 という值（紫色と赤色の境となる值）に着 目すると, 劣化が無い場合（図-9), 供試体上面では, その值は供試体の右端より $250 \mathrm{~mm}$ 弱の箇所に位置し ているが，分極抵抗が小さくなるにしたがって，その值 を示す箇所は右側にシフトしていることが分かる．この 場合, 被測定面積は小さくなる. 図-10から図-12 は $100 \mathrm{~mm}$ の劣化領域を供試体の中央（解析メッシュでは 右端）から $100 \mathrm{~mm}$ のところに設けたケースであるが, 図-13 から図-15 は, 分極抵抗比が $1 / 2$ のケースについ て, $100 \mathrm{~mm}$ の劣化領域を供試体の中央（解析メッシュ では右端）から $200 \mathrm{~mm} （ 200 \sim 300 \mathrm{~mm}$ 区間，図-8 の 緑色の領域), $300 \mathrm{~mm}(300 \sim 400 \mathrm{~mm}$ 区間, 図-8 の黄 色の領域）ならびに $400 \mathrm{~mm}$ （400〜 500 mm 区間，図-8 


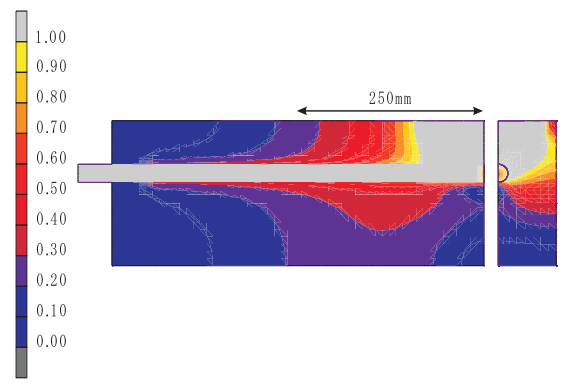

図-9 電流密度分布図 (劣化なし)

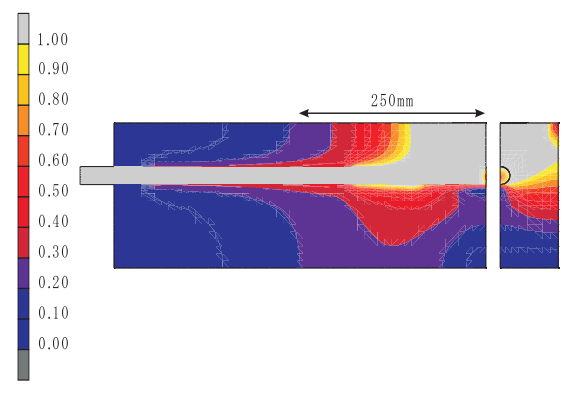

図-10 電流密度分布図 (分極抵抗比 $1 / 2$ )

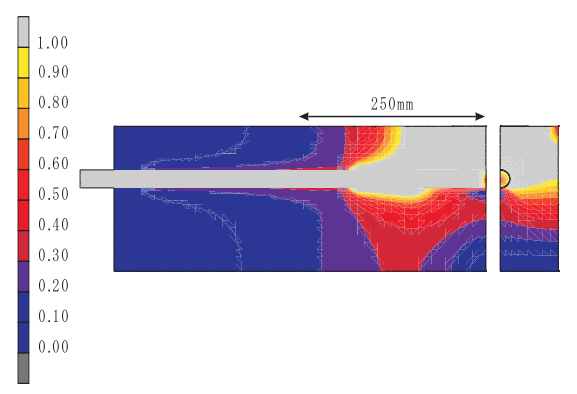

図-11 電流密度分布図 (分極抵抗比 $1 / 5$ )

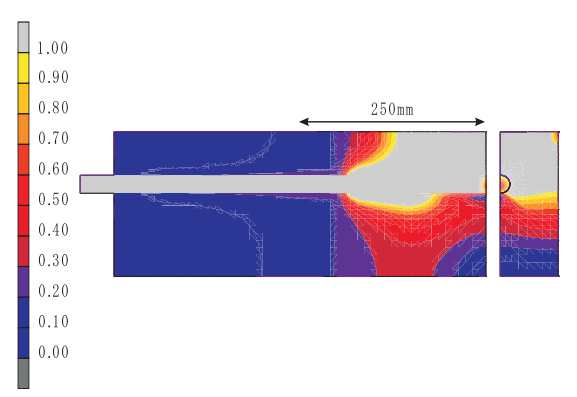

図-12 電流密度分布図 (分極抵抗比 $1 / 10$ )

の青色の領域）の箇所に設けた場合の電流密度分布図 である. 図-10 ならびに図-13 から図-15より，劣化 領域の移動にともなって躯体内を伝播する電流の状況 が変化している，それは躯体内部の鉄筋付近，特に劣 化領域前後で顕著であるが，身体の上面（印加した面） 近傍では若干の変化が確認できる程度である. 劣化領 域が印加部から遠ざかることで被測定面積も大きくな る可能性があるが，劣化領域そのものが広いわけでは ないので，分極抵抗法を用いて評価する場合には，こ

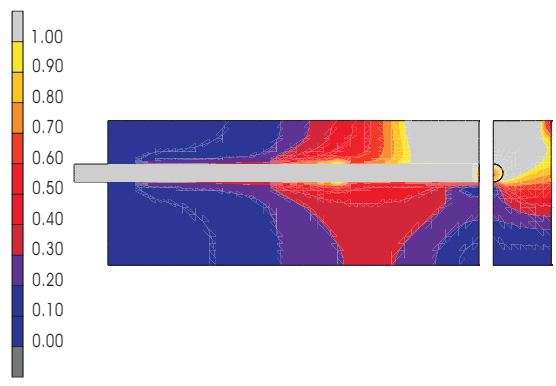

図-13 電流密度分布図 (劣化領域 200-300 mm)

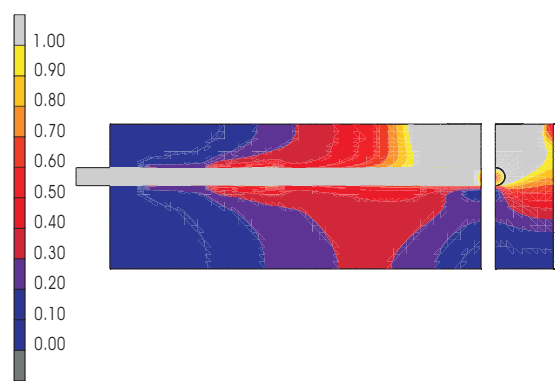

図-14 電流密度分布図 (劣化領域 300-400 mm)

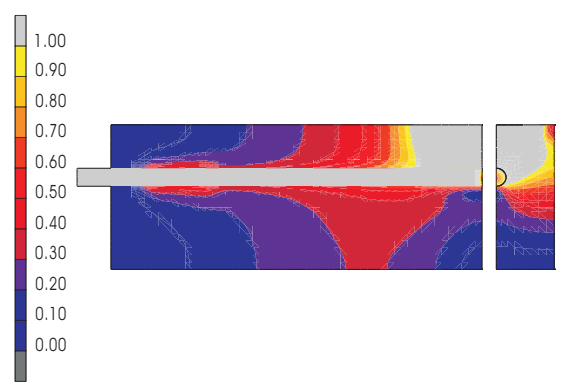

図-15 電流密度分布図 (劣化領域 400-500 mm)

のようなことに留意すべきと考える.

\section{（2）不動態皮膜の劣化領域の大小について}

本小節では, 不動態皮膜の劣化領域の大小が被測定 面積および電流伝播に及ぼす影響の把握を目的として 解析を行った．劣化部における分極抵抗比を $1 / 2$ とし, 不動態皮膜の劣化領域の大きさは, 前小節の $100 \mathrm{~mm}$ に 対して， $250 \mathrm{~mm}$ と 2.5 倍の大きさとした. なお，この 劣化領域が $250 \mathrm{~mm}$ の箇所については, 供試体の中央 (解析メッシュでは右端) から $50 \mathrm{~mm}$ ならびに $250 \mathrm{~mm}$ の 2 パターンを考えた. なお，その他のパラメータに ついては，すべて前小節と同じものを用いている.

劣化区間が 50-300 mm の図-16 と劣化区間が 100$200 \mathrm{~mm}$ の図-10 を比較すると, 前者については鉄筋下 部への電流の回りこみがやや顕著となっているが，両 者にそれほど大きな差は認められない。他方, 劣化区 間が 250-500 mm の図-17 の場合は，印加された電流 はコンクリート部を伝播してより広く遠方に拡散して 


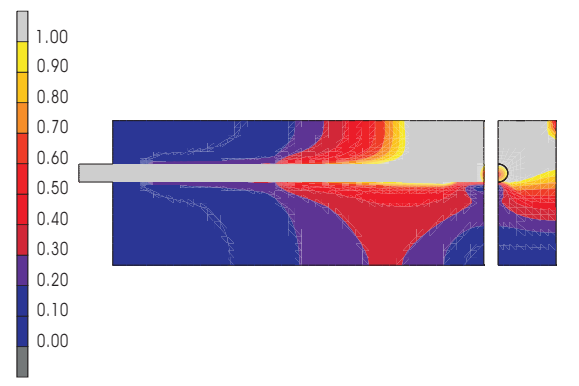

図-16 電流密度分布図 (分極抵抗劣化領域 50-300 mm)

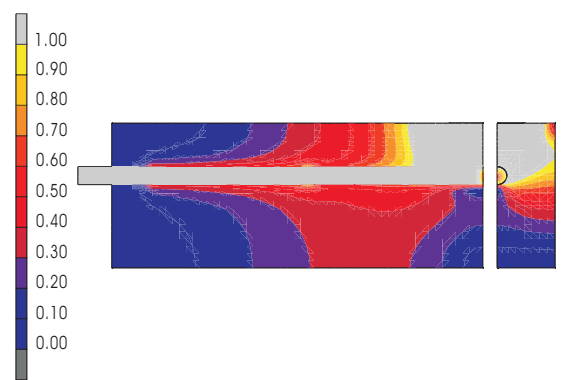

図-17 電流密度分布図 (分極抵抗劣化領域 250-500 mm)

表-2 不動態皮膜の劣化の経時変化

\begin{tabular}{|c|c|c|}
\hline $\begin{array}{c}\text { 養生期間 } \\
(\text { 週 })\end{array}$ & $\begin{array}{c}\text { 不動態皮膜の分極抵抗 } \\
R_{p}\left(\mathrm{k} \Omega \mathrm{cm}^{2}\right)\end{array}$ \\
\hline 30 & \multicolumn{2}{|c|}{1000} \\
\hline 50 & 708.8 & 735.3 \\
\hline 70 & 417.7 & 470.6 \\
\hline 90 & 126.5 & 205.9 \\
\hline 98 & 10.0 & 100.0 \\
\hline
\end{tabular}

いる様子が明確となっており，明らかに前者の 2 つと は異なる。これより，劣化区間が長くなっても，被測 定面積が大きく変化するとは限らず，むしろ，印加部 と劣化箇所に電流伝播は依存し，劣化区間が短くても， それが印加部から遠方にあると，被測定面積は，見か け上，大きく評価される可能性があることが示唆され ている.

\section{（3）コンクリート抵抗率と不動態皮膜の分極抵抗の経 時変化について}

本小節では, コンクリートの乾燥や不動態皮膜の劣 化, すなわち, コンクリート抵抗率や不動態皮膜の分 極抵抗が時間とともに变化した場合における被測定面 積および電流伝播に及ぼす影響を把握することを目的 に解析を行った。 なお，コンクリートの抵抗率の経時変 化については表-1に，また，不動態皮膜の分極抵抗の 経時変化については表-2に従うものとした。この解析 では，これまでの解析と異なり不動態皮膜の劣化は部

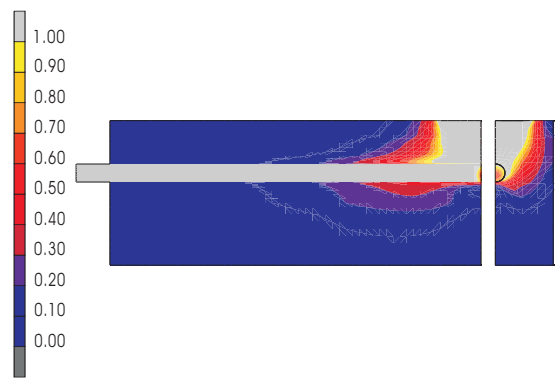

図-18 電流密度分布図 (70 週, 劣化速度大)

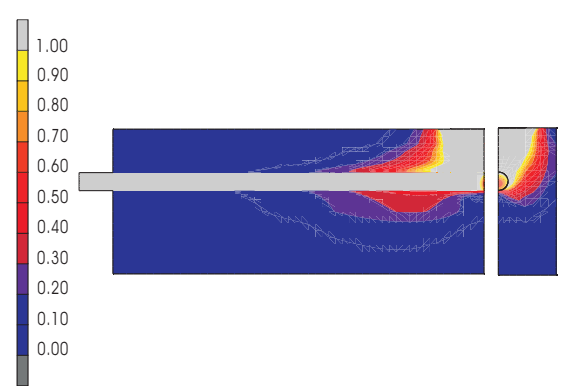

図-19 電流密度分布図 (70 週, 劣化速度小)

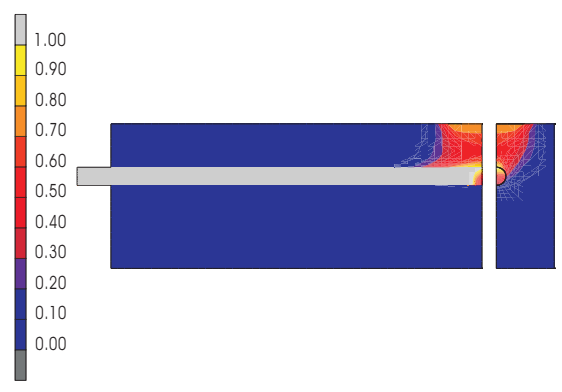

図-20 電流密度分布図 (98 週, 劣化速度大)

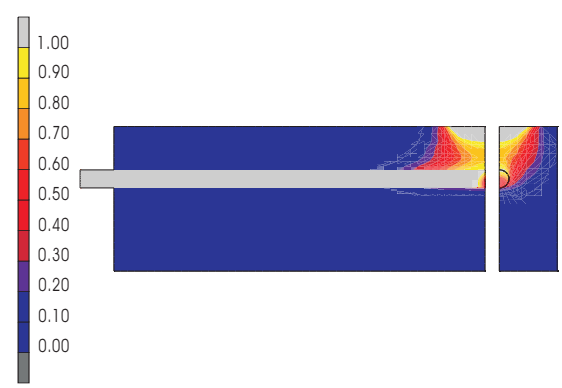

図-21 電流密度分布図 (98 週, 劣化速度小)

分的なものではなく, 全面劣化を想定している. なお, 98 週後に分極抵抗が $1000 \mathrm{k} \Omega \mathrm{cm}^{2}$ から $10 \mathrm{k} \Omega \mathrm{cm}^{2}$ 一変 化する方が， $1000 \mathrm{k} \Omega \mathrm{cm}^{2}$ から $100 \mathrm{k} \Omega \mathrm{cm}^{2}$ 一変化する 場合よりも劣化速度が速いことを意味している。

全ての週の解析結果を掲載することは, 紙面の関係 上難しいため, 本論文では 70 週時における電流の電流 密度分布図を図-18 と図-19 に，また，98 週時におけ る電流密度分布図を図-20 と図-21に示す，いずれも， 前者の方が後者よりも腐食速度が速い事例となる. 70 
週時については劣化速度を変化させても, 電流の伝播 状況に大きな差は認められないが，98 週時では劣化速 度の変化によって電流の伝播状況も若干ではあるが変 化している様子が伺える. 全面劣化をしていることか ら, 特定の地点で電流密度が高まるということは認め られない. 70 週時と 98 週時を比較すると, 前者より後 者の方が電流伝搬の広がりが抑制されていることが伺 える.これは, 98 週時の方がコンクリートの乾燥が進 んで抵抗が大きくなることで，コンクリート中を電流 が伝播しにくいためである。これより，養生期間が短 い場合は，不動態皮膜の腐食速度にかなりの差があれ ば電流の伝播状況も変化するかもしれないが，本解析 で設定したような変化の程度の下では，養生期間が短 い場合に限れば電流伝播に大きな差がないものの, 時 間経過とともに少しずつ差が生じることが示唆されて いる.

\section{（4）コンクリート抵抗率と不動態皮膜の分極抵抗の経 時変化および劣化箇所による比較}

前小節と同様にコンクリート抵抗率と分極抵抗を経時 変化させるとともに, 不動態皮膜の劣化箇所の違いが被 測定面積および電流伝播に及ぼす影響を把握することを 目的に解析を行った. 不動態皮膜の劣化箇所は小節 (1) と同様とし， $100 \mathrm{~mm}$ の劣化領域を供試体の中央（解析 メッシュでは右端）から $100 \mathrm{~mm} （ 100 \sim 200 \mathrm{~mm}$ 区間, 図-8 のクリーム色の領域），200 mm（200〜300 mm 区間，図-8 の緑色の領域），300 mm（300〜 400 mm 区間，図-8 の黄色の領域)）ならびに $400 \mathrm{~mm}$ (400〜 $500 \mathrm{~mm}$ 区間, 図-8 の青色の領域) の箇所に設けたケー スである. なお，不動態皮膜の劣化による分極抵抗の 経時変化パターンとしては， $1000 \mathrm{k} \Omega \mathrm{cm}^{2}$ (30 週時) か ら $100 \mathrm{k} \Omega \mathrm{cm}^{2}$ (98 週時) に変化するパターン（劣化速 度小）を採用した. 図-22〜図-25に 70 週時の, また, 図-26〜図-29 に 98 週時の電流密度分布図を示寸.

70 週時の分極抵抗は 30 週時の半分弱となっている ので，コンクリートの乾湿は考慮していない解析にお いて分極抵抗比を $1 / 2$ としたケース（図-10 ならびに 図-13 から図-15）と比較が可能となるが，コンクリー 卜の乾湿を考慮しない場合は, 不動態皮膜の劣化領域 における電流流入が顕著であったのに対し, コンクリー 卜の乾湿を考慮した場合は, それがあまり顕著となっ ていない。これは，コンクリートが乾燥することで抵 抗值が大きくなり, コンクリート中を電流が流れ難く なり, 印加直下への電流の流れが卓越することに起因 している. コンクリートが乾燥する場合, 不動態皮膜 の劣化領域の箇所に関わらず, 被測定面積に差異が出 難くなることから, 分極抵抗法では, 不動態皮膜の劣 化を的確に捉えられない可能性がある.
他方, 98 週時の分極抵抗は 30 週時の $1 / 10$ まで低減 していることから， 70 週時と比較すると，不動態皮膜 の劣化領域一の電流の流れ込みがやや明㙩となってい るが，劣化領域が印加部より離れている場合（図-29）, コンクリート中に電流が流れないことに起因して, 不 動態皮膜の劣化領域一の電流の流れ込みは, 一転, 不 明瞭となっている．このように，不動態皮膜のみに劣 化が生ずる場合と比較して, 不動態皮膜の劣化とコン クリートの乾燥がともに生じると, 電流の伝播状況は 非常に複雑になることがわかる.

\section{6. インピーダンス特性曲線}

文献によれば ${ }^{28)}$ ，インピーダンス特性曲線を作成す ることで, コンクリート抵抗率や分極抵抗が電流分散 状況および被測定面積に及ぼす影響を考慮できるよう になり, 鉄筋腐食診断器により測定される見かけの分 極抵抗 $R_{p}^{\prime}$ から真の分極抵抗 $R_{p}$ を従来よりも精度よく 評価できるようになる，そこで，本研究においても，上 述した解析に関して, インピーダンス特性曲線を作成 することとした.

コンクリート抵抗率 $\rho$ とかぶり $t$ の積がかぶりコンク リートの抵抗 $R_{s}\left(R_{s}=\rho \times t\right)$, 真の分極抵抗 $R_{p}$ を被 測定面積 $A$ で割った值が見かけの分極抵抗 $R_{p}^{\prime} \quad\left(R_{p}=\right.$ $\left.R_{p}^{\prime} \times A\right)$ である. 真の分極抵抗 $R_{p}$ とかぶりコンクリー 卜の抵抗 $R_{s}$ の和を全抵抗 $R_{T}\left(R_{T}=R_{p}+R_{s}\right)$, 見か けの分極抵抗 $R_{p}^{\prime}$ とかぶりコンクリートの抵抗 $R_{s}$ との 和を見かけの全抵抗 $R_{T}^{\prime}\left(R_{T}^{\prime}=R_{p}^{\prime}+R_{s}\right)$ とし, 全抵 抗 $R_{T}$ ならびにみかけの全抵抗 $R_{T}^{\prime}$ をそれぞれかぶり コンクリートの抵抗 $R_{s}$ で割った值をそれぞれ横軸なら びに縦軸にプロットすることで，インピーダンス特性 曲線を得ることができる ${ }^{28)}$.

一般に, 実験により得られたインピーダンス特性曲 線では, 不動態皮膜ならびにコンクリートの非均一性 を評価することはできないため, 本研究の解析より得 られたインピーダンス特性曲線と実験により得られた インピーダンス特性曲線を比較することで, 不動態皮 膜の劣化やコンクリートの乾燥等がインピーダンス特 性曲線に及ぼす影響を検討する。

図-30 は, 塩化物を添加して鉄筋腐食を促進させた実 験（青色系統）と, 何も添加しない実験（赤色系統）に おけるインピーダンス曲線である ${ }^{35}$. 実験では, 鉄筋 腐食を促進させた実験（青色系統）の場合, $R_{T} / R_{s}$ の 值は 1.0 から 2.0 の間にあり, 何も添加しない実験（赤 色系統）の場合， $R_{T} / R_{s}$ の值はほとんどが 3.0 以上と なっているというように添加物の有無によってはっき りとタイプが分かれており, 通常, このような整理に よって鉄筋の腐食等が議論されることが多い. 


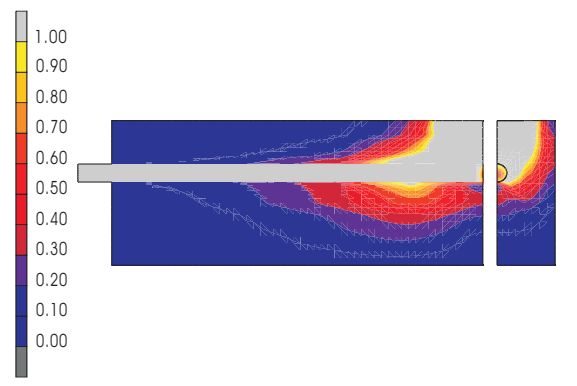

図-22 電流密度分布図 (70 週, 劣化領域 100-200 mm)

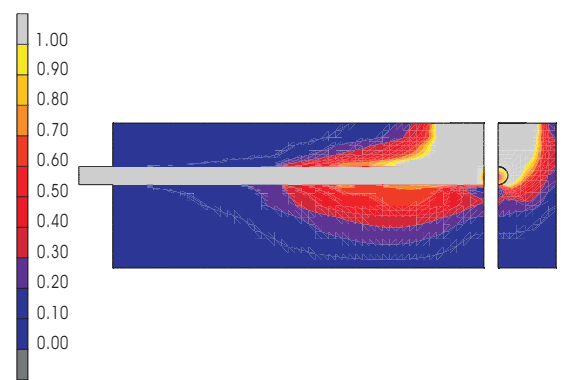

図-23 電流密度分布図 (70 週, 劣化領域 200-300 mm)

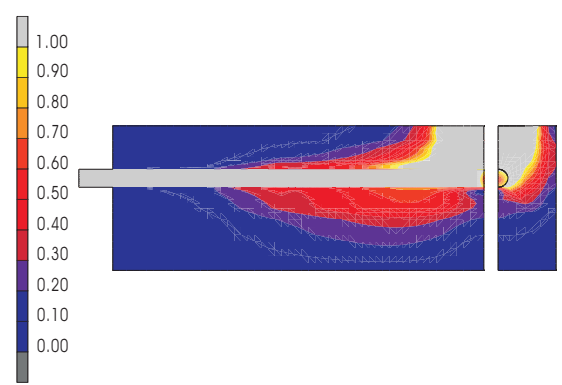

図-24 電流密度分布図 (70 週, 劣化領域 300-400 mm)

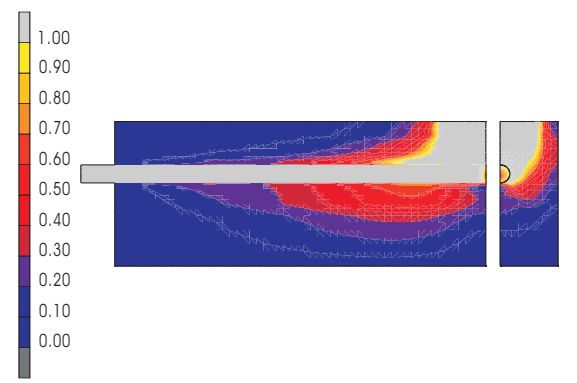

図-25 電流密度分布図 (70 週, 劣化領域 400-500 mm)

図-31 は，以下に示寸ような解析例におけるインピー ダンス曲線である。ここでは，不動態皮膜の劣化箇所を 小節 (1) と同様とし, $100 \mathrm{~mm}$ の劣化領域を供試体の中 央（図-8 の右端）から $100 \mathrm{~mm} （ 100 \sim 200 \mathrm{~mm}$ 区間で 図-8 のクリーム色の領域)，200 mm（200〜300 mm 区 間で図-8 の緑色の領域)，300 mm（300〜 400 mm 区間 で図-8 の黄色の領域) ならびに $400 \mathrm{~mm}$ (400〜 $500 \mathrm{~mm}$ 区間で図-8 の青色の領域）の箇所に設けている。また, この劣化箇所における分極抵抗比は $1 / 10$ で固定とし,

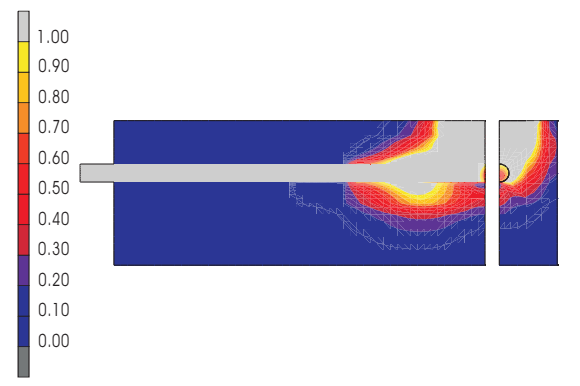

図-26 電流密度分布図 (98 週, 劣化領域 100-200 mm)

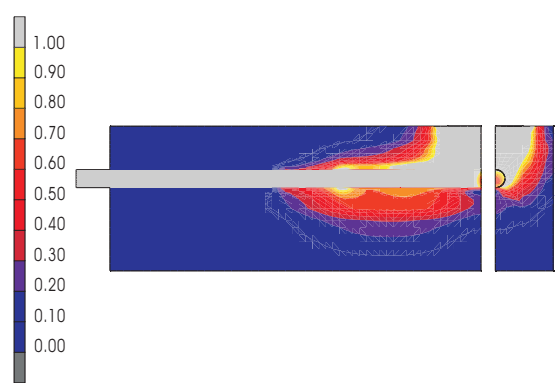

図-27 電流密度分布図 (98 週, 劣化領域 200-300 mm)

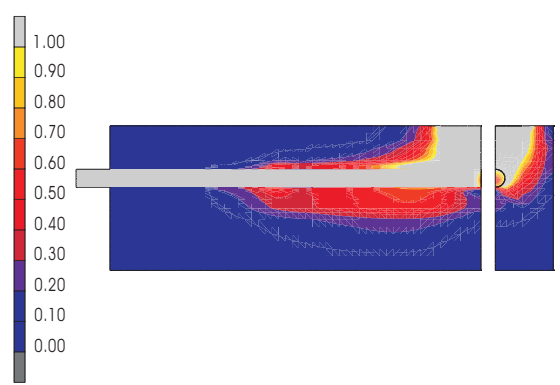

図-28 電流密度分布図 (98 週, 劣化領域 300-400 mm)

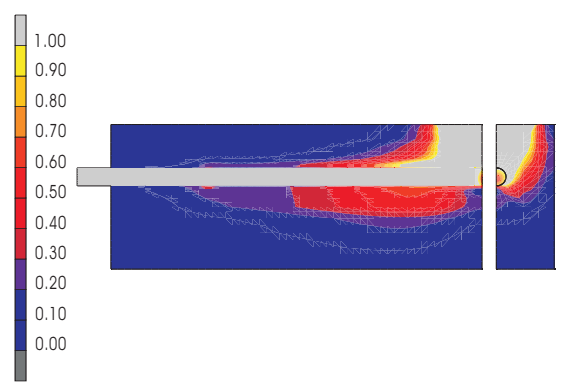

図-29 電流密度分布図 (98 週, 劣化領域 400-500 mm)

分極抵抗の経時変化 (劣化速度) は考慮していないが, コンクリートについては乾燥を考慮し, コンクリート の抵抗率の経時変化については表-1に従うものとして いる. インピーダンス曲線をプロットするにあたって は, 真の全抵抗 $\left(R_{T}\right.$, 横軸 $)$ と見かけの全抵抗 $\left(R_{T}^{\prime}\right.$,

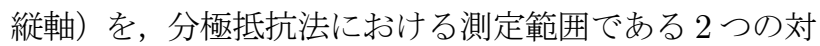
極センサー間のコンクリートの抵抗 $R_{s}$ で除すことにな る. しかしながら，この処理をするにあたって，同じ 98 週時の解析結果でも, 印加直下のコンクリートの抵抗 


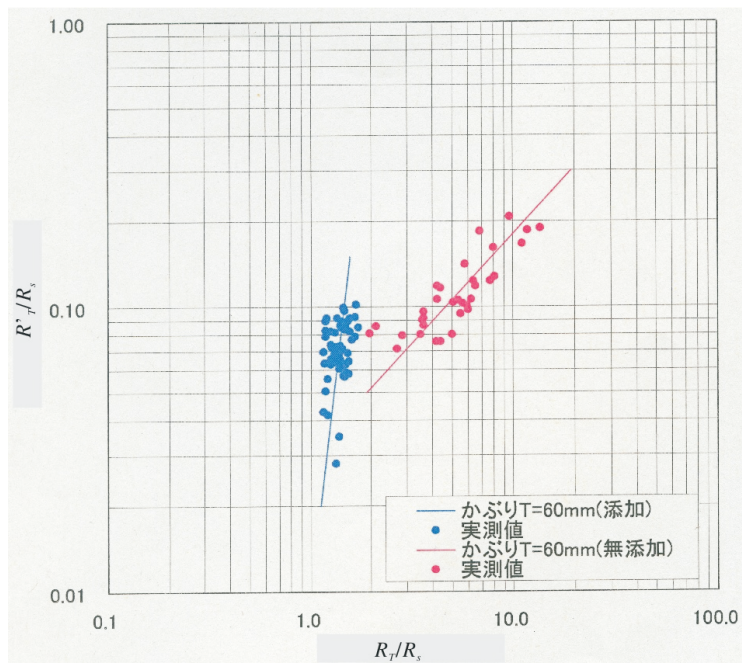

図-30 実験により得られたインピーダンス特性曲線 ${ }^{35)}$

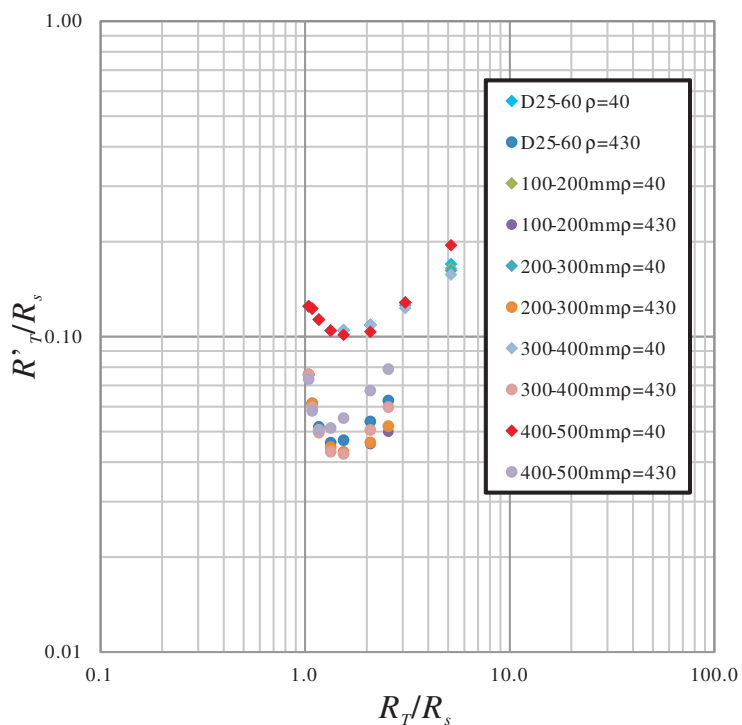

図-31 分極抵抗比 $1 / 10$ の下でコンクリートの乾燥を考慮し た解析のインピーダンス特性曲線

率 (本解析では $\rho=430 \mathrm{k} \Omega \mathrm{cm}^{2}$ ) を用いる場合と鉄筋直 上のコンクリートの抵抗率 (本解析では $\rho=40 \mathrm{k} \Omega \mathrm{cm}^{2}$ ) を用いる場合では，大きくグラフ形状が異なってくる. それを示したのが図-31 である，実際には，下限值で ある $\rho=40 \mathrm{k} \Omega \mathrm{cm}^{2}$ と上限值である $\rho=430 \mathrm{k} \Omega \mathrm{cm}^{2}$ の間 の值，つまり材料としての代表值を用いるべきかもし れないが，それは場所やコンクリートの材齢によって異 なる可能性もあるため, その評価によってはインピー ダンス曲線にプロットされる点はばらつくことが予想 される．図-31 はそれを示した例である，全抵抗ある いは見かけの抵抗を大きな值の $R_{s}$ で除すとプロット点 が左下方にズレるため, $\rho=430 \mathrm{k} \Omega \mathrm{cm}^{2}$ にて処理した場 合 (○の記号系) ) は $\rho=40 \mathrm{k} \Omega \mathrm{cm}^{2}$ にて処理した場合

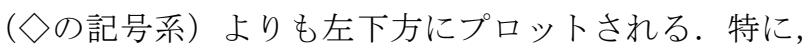
$\rho=430 \mathrm{k} \Omega \mathrm{cm}^{2}$ にて処理した場合, $R_{T} / R_{s}$ の值はすべ て 3.0 を下回っており, 養生期間が増すにつれて左にシ

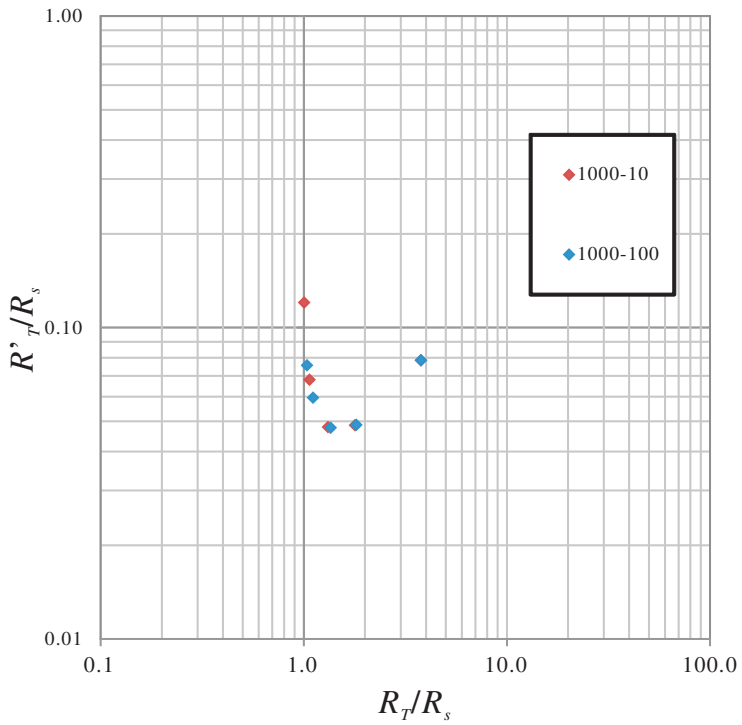

図-32 小節 $(3)$ より得られた劣化速度に着目したインピーダ ンス特性曲線

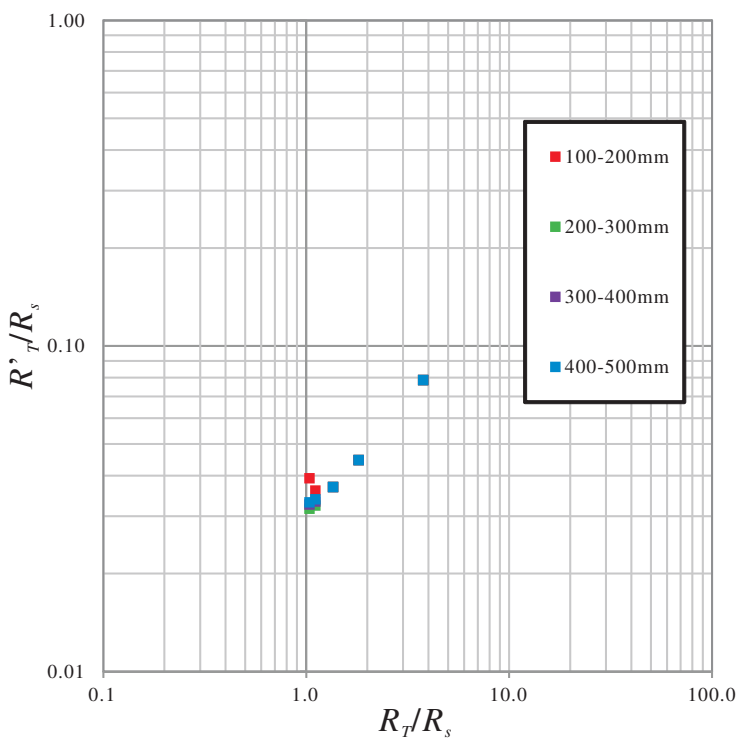

図-33 小節 (4) より得られた劣化箇所に着目したインピーダ ンス特性曲線

フトし, 70 週以降は 2.0 を下回っている. 図-30 と比 較すると, $R_{T} / R_{s}$ の值が 2.0 を下回った場合は「塩化 物を添加して鉄筋腐食を促進させた実験（青色）」が示 寸分布に近くなる.

図-32 は，小節 (3)，つまりコンクリートの乾燥を 考慮してコンクリートの抵抗率を変化させるだけで なく，不動態皮膜の劣化を考慮して分極抵抗を初期の $1000 \mathrm{k} \Omega \mathrm{cm}^{2}$ から $10 \mathrm{k} \Omega \mathrm{cm}^{2}$ （劣化速度大）まで，ある いは $100 \mathrm{k} \Omega \mathrm{cm}^{2}$ （劣化速度小）まで低下させた事例に ついて，各週（養生期間 30 週，50 週，70 週，90 週，98 週）ごとの解析結果を基に作成したインピーダンス曲 線である.なお，この事例では，不動態皮膜は全面劣化 しているものとしている. 図では, 横軸の $R_{T} / R_{s}$ が大 きい方から養生期間 30 週，50 週，70 週，90 週，98 週 
となっている. 図より, 劣化速度が速い場合（赤点）と 遅い場合（青点）を比較すると, コンクリートの乾燥と 不動態皮膜の劣化が進行している 90 週後や 98 週後で は, 劣化速度の速い場合（赤点）は同じ $R_{T} / R_{s}$ の值の ときの $R_{T}^{\prime} / R_{s}$ の值が大きくなっているが， 70 週以前だ と, 劣化速度による左派ほとんど無い. 70 週後の電流 密度分布である図-18（劣化速度大）と図-19（劣化速 度小）を比較すると，両者にそれほど大きな差は無い。 これは 70 週の時点では, 両ケースにおける分極抵抗に ほとんど差がないが（表-2 を参照），90 週，98 週と なると両者に差が生じ, 図-20 (劣化速度大) と図-21 (劣化速度小) に示寸ように, 電流の伝播状況が変化し ている. 劣化速度が速い場合 (赤点) の方が劣化速度が 小さい場合（青点）よりも印加部直下に電流が集中し ていることから被測定面積 $A$ が小さく, 見かけの分極 抵抗 $R_{T}^{\prime}$ は大きくなるため, 劣化速度が速い場合（赤 点）では, 図-32 に示す通り, プロット点が上部に位 置している. なお, 50 週以降は $R_{T} / R_{s}$ の值が 2.0 を下 回っており, 図-30 と比較すると,「塩化物を添加して 鉄筋腐食を促進させた実験 (青色)」が示寸分布に近く なる.

図-33 は，小節 (4), つまりコンクリートの乾燥を考 慮してコンクリートの抵抗率を, また, 不動態皮膜の 劣化を考慮して分極抵抗を変化させるが，その不動態 皮膜の劣化領域は全面的ではなく, 部分的であるとし て解析した場合のインピーダンス曲線である，凡例は， 劣化領域の箇所を表している. なお, この場合も, 図の 横軸の $R_{T} / R_{s}$ が大きい方から養生期間 30 週, 50 週, 70 週, 90 週, 98 週となっている. 図より, 養生期間が 短い場合は, 劣化箇所による差はほとんどない（点は 重なっているため, 青色しか見えていない）が，この 場合も 90 週, 98 週となると, 劣化箇所によって值が 若干異なっていることがわかる. しかしながら, 上述 した劣化速度を変化させた場合の変化量と比較すると, 劣化箇所による影響はあまり大きくないことがわかる. なお, この場合も 50 週以降は $R_{T} / R_{s}$ の值が 2.0 を下 回っており，これも図-30 と比較すると，「塩化物を添 加して鉄筋腐食を促進させた実験（青色）」が示す值分 布とに近くなる.

これらの結果より, 図-30の青点に関する回帰式と 鉄筋の腐食等に強い相関があるとは限らず, 図-31 か ら図-33にて考察したように, 鉄筋の腐食（本研究で は不動態皮膜の劣化）だけではなく、コンクリートの乾 燥にともなうコンクリートの抵抗率の変化もまた, イ ンピーダンス曲線に大きな影響を及ぼしていると思わ れる.したがって, コンクリートの乾燥による影響を 加味せずに鉄筋の腐食評価をする際には議論の必要が あるものと思われる. 一方, まだ解析事例が極めて少
ないことから, 今後, 解析パターンを増やしてパラメ トリックスタディをする他, 実験との比較を通して, 解 析の妥当性を深めつつ, 最終的には, コンクリートの 乾燥や不動態皮膜の劣化がインピーダンス曲線に与え る影響を詳細に検討する必要があろう。

\section{7. まとめ}

本研究では, 鉄筋コンクリート構造物に用いられる 鉄筋の腐食検查・診断法の 1 つである分極抵抗法に着目 し, その適用性等の議論を行うために, 不動態皮膜の 劣化による分極抵抗の非均一性ならびにコンクリート の乾湿にともなう抵抗率の非均一性が電流分散状況に 及ぼす影響について調べることを目的とし, 電流伝播 に関する 3 次元有限要素解析を行った. 解析にあたって は, 不動態皮膜における分極抵抗の值, 劣化箇所とそ の大きさ，そしてコンクリートの抵抗率のを変化させ てパラメトリックスタディを実施した。 その結果, 不動 態皮膜における分極抵抗の值, 劣化箇所とその大きさ もさることながら，コンクリートの乾湿にともなう抵 抗率の変化が供試体中を流れる電流の分散状況に大き な影響を与えることが判明した．また，コンクリート の乾湿にともなう抵抗率の変化等を考慮に入れない場 合, 鉄筋腐食の程度等の把握が複雑となる可能性があ ることも示唆された. しかしながら, まだ, 解析数が十 分でないことに起因して普遍的な知見を得るに至って いないことから，実験等との比較も行って解析の妥当 性を検証し, その上で, 分極抵抗法の利活用できる状 況や適用範囲等をより詳細に議論する必要があろう。

\section{参考文献}

1) 国土交通省: 平成 25 年度国土交通白書, pp.28-29, 2014 .

2) 土木学会 : 2001 年制定コンクリート標準示方書 維持管 理編, pp.102-104, 2001.

3）枝広英俊, 十代田知三, 竹内昌彦, 山本祐基子 : 自然電 位法によるコンクリート中の鉄筋の腐食評価に関寸る研 究, コンクリート工学年次論文報告集, Vol.20, No.1, pp.311-316, 1998.

4) 中村英佑, 渡辺博志, 古賀裕久, 中村雅之, 井川一弘 : 塩害環境下にあるコンクリート構造物への自然電位法の 適用に関する研究, 土木学会論文集 $\mathrm{E}, \mathrm{Vol} .64$, No.1, pp.263-275, 2008.

5) 福山聡子, 野口貴文, 兼松学, 林永哲: 交流インピーダン ス法を用いた鉄筋腐食の非破壊検查に関する基礎的研究, 日本建築学会大会学術講演梗概集, pp.185-186, 2006.

6) 斯波明宏, 樋口正典: 電気化学的鉄筋腐食測定法の適用 性に関する研究, 三井住友建設技術研究所報告, 第 5 号, pp.79-84, 2007.

7）松村卓郎, 金津努, 石田博彰: コンクリート中の鉄筋腐食 の非破壊検査法の開発 -2 種類の周波数を用いた分極抵 抗法の適用性一, 電力中央研究所報告, U920523, 22p, 1993.

8) 露口雄次, 町田篤彦: 直流比抵抗法を用いた $\mathrm{RC}$ 構造 物の内部推定に関する基礎的研究, 土木学会論文集 $\mathrm{E}$, Vol.62, No.4, pp.641-656, 2006. 
9) 露口雄次, 町田篤彦: 直流比抵抗法を用いたコンクリー 卜構造物の内部推定に関寸る基礎的研究，土木学会第 60 回年次学術講演会概要集, 5-590, pp.1179-1180, 2005.

10）露口雄次, 町田篤彦: 直流比抵抗法を用いた鉄筋腐食度 推定手法の実用化, 土木学会第 62 回年次学術講演会概 要集, 5-016, pp.31-32, 2007.

11）露口雄次, 町田篤彦: 鉄筋腐食度推定に関寸る電気探査 法と既存測定法の比較検討, 土木学会第 63 回年次学術 講演会概要集，5-176, pp.351-352， 2008.

12）露口雄次, 町田篤彦: 電気探査法を応用した $\mathrm{RC}$ 構造物の 鉄筋位置と腐食状態の推定, 土木学会論文集 E, Vol.64, No.1, pp.42-61, 2008.

13）小林孝一, 宮川豊章 : 分極抵抗法を用いた鉄筋の腐食速 度評価に関する研究，土木学会論文集，No.669, V-50, pp.173-186, 2001.

14）独立行政法人土木研究所 : コンクリート構造物の鉄筋腐 食診断技術に関寸る共同研究報告書一自然電位法・分極 抵抗法による鉄筋腐食診断一, pp.5-37, 2003.

15) 横田優, 上田隆雄 : 建設後 24 年経過した地下道側壁の 鉄筋腐食モニタリング結果について, 土木学会第 55 回 年次学術講演会, V-467, pp.936-937, 2000.

16) 横田優 : 建設後 36 年経過した RC 造開水路側壁の腐食 モニタリング結果について，コンクリート工学年次論文 報告書, Vol.20, No.1, pp.185-190, 1998.

17）横田優: 交流インピーダンス測定による水中浸漬に伴うコ ンクリート中にある鉄筋の腐食進行評価，日本材料学会四 国支部第 8 回学術講演会講演論文集，S5-16, pp.31-32, 2010.

18）横田優，上田隆雄: 分極抵抗法に基づく鉄筋腐食非破壊検 查方法の実構造物一の適用試験, 土木学会四国支部第 5 回技術研究発表会講演概要集, V-14, pp.340-341， 1999.

19）横田優, 浮田和明, 幸英昭: 交流インピーダンス法によ るコンクリート中の鉄筋腐食評価，土木工学における非 破壊評価シンポジウム講演論文集, pp.241-246, 1991.

20）横田優, 松場新吾, 松田耕作 : 室内気中にて長期養生し たコンクリート供試体の鉄筋腐食に関する考察, 土木学 会四国支部第 16 回技術研究発表会講演概要集, V-15, pp.297-298, 2010.

21) 横田優, 河野清: 交流インピーダンス法によるコンクリー 卜中の鉄筋腐食診断について, 土木学会第 49 回年次学 術講演会, V-88, pp.176-177, 1994.

22）濱田秀則, 平崎敏史，山路徹，Tarek U.M. : コンクリー 卜中鉄筋の電気化学的計測に影響を及ぼす要因に関する 実験的考察，コンクリート工学論文集，Vol.15, No.1, pp.57-67, 2004 .
23）鈴木僚, 西村次男, 加藤佳孝, 横田弘, 岩波光保, 加藤 絵万 : 測定環境条件が鉄筋コンクリートの電気化学的測 定結果に及ぼす影響, 生産研究, 59 巻, 3 号, pp.9-10, 2007.

24）松岡和巳，松井繁之：インピーダンス特性曲線を用いた 分極抵抗值の逆推定法の適用性評価, 土木学会第 58 回 年次学術講演会概要集, V-079, pp.157-158, 2003.

25）松岡和巳，松井繁之: 交流インピーダンス測定における コンクリート中電流分布特性に関する研究, 土木学会第 57 回年次学術講演会, V-169, pp.337-338, 2002.

26) 松岡和巳, 松井繁之: 数值解析を用いた交流インピーダ ンス測定值の定量的評価法について, コンクリート工学 年次論文集, Vol.25, No.1, pp.839-844, 2003.

27）岡田英哲, 松岡和巳, 大西弘志, 松井繁之：分極抵抗測 定値に及ぼす各種パラメータの影響評価，土木学会第 59 回年次学術講演会概要集, 5-268, pp.533-534, 2004.

28）金田尚志，松岡和巳：BEM による電流分布シミュレー ションと鉄筋の分極抵抗值の推定，コンクリート工学年 次論文集，Vol.33，No.1，pp.1715-1720，2011.

29) 吉田秀典, 川上 純, 荒木志帆, 横田 優 : 電流分散範囲 を考慮した分極抵抗評価に関する数值解析的研究，土木 学会論文集 A2, Vol.69, No.2, pp.I_667-I_688, 2013.

30) 北峯博司, 関博, 金子雄一: コンクリートの含水率と抵 抗率に関する実験的研究, 土木学会第 45 回年次学術講 演会, V-374, pp.774-775, 1990.

31）生田周史，中川元宏，山本貴士，服部篤史，宮川豊章: 各 種要因がコンクリートの比抵抗に与える影響に関する実 験的研究, 土木学会第 59 回年次学術講演会, pp187-188, 2004.

32 ）金田尚志，松岡和巳，嶋野慶次，青木優介：コンクリー 卜表面から深さ方向の比抵抗の経時変化, コンクリート 工学年次論文集, Vol.36, No.1, pp.2098-2103, 2014.

33) 松浦聰: 橋梁保全のための電気防食工法の施工，2010 年 第 31 回夏季研修会論文, 藤井基礎設計事務所, pp.85-96, 2011.

34）小川勤，伊東賢伸，梅木芳人，島本龍，坂詰義幸，横田 優 : 分極抵抗法の原子力関連施設への適用性に関する研 究 (その 1 試験計画と評価方法), 日本建築学会大会学 術講演梗概集，pp.1321-1322， 2012.

35）坂詰義幸, 伊東賢伸, 小川勤, 梅木芳人, 島本龍, 横田 優: 分極抵抗法の原子力関連施設一の適用性に関する研究 (その 2 インピーダンス特性曲線の作成と測定結果の評 価）, 日本建築学会大会学術講演梗概集, pp.1323-1324, 2012.

(2016. 6. 24 受付)

\title{
STUDY ON INFLUENCE OF DEGRADATION OF PASSIVATION FILM OR WETTING AND DRYING OF CONCRETE ON PROPERTY OF ELECTRICAL CONDUCTION
}

\author{
Hidenori YOSHIDA and Shuhei OHMOTO
}

\begin{abstract}
Recently, the polarization resistance method is highly noticed as a non-destructive test method to evaluate the corrosion rate of rebar in concrete structures. The corrosion rate can be estimated from the apparent polarization resistance and the polarized area. The polarized area is often evaluated by numerical methods such as boundary element method. The material heterogeneity such as rebar corrosion or altered concrete is one of the most important affectors on the current propagation in a reinforced concrete. However, it is not well evaluated by boundary element method. Thus, in this study, finite element method is employed to evaluate the current propagation. In the results, the properties of current propagation are strongly affected by the material heterogeneity.
\end{abstract}

